\title{
TRANSFORMATIONS OF PROTEIN IN POLYMERS OF ANIMAL ORIGIN
}

O. Okhmat, O. Mokrousova, L. Maistrenko

Kyiv National University of Technologies and Design

\begin{tabular}{|c|c|}
\hline Key words: & ABSTRACT \\
\hline $\begin{array}{l}\text { Collagen structure } \\
\text { Liming processes of skin } \\
\text { production } \\
\text { Hydroxyl and carboxyl- } \\
\text { containing products } \\
\text { Protein transformation }\end{array}$ & $\begin{array}{l}\text { The skin of animals is a biological object. Its structure is } \\
\text { formed by the spatial form of collagen. In the technology of } \\
\text { production, the structure of the protein undergoes chemical, } \\
\text { physical and mechanical transformation. The processes of } \\
\text { production of genuine leather are based on the effect of che- } \\
\text { mical reagents on the protein component. This action leads }\end{array}$ \\
\hline $\begin{array}{l}\quad \text { Article history: } \\
\text { Received } 08.11 .2018 \\
\text { Received in revised form } \\
22.11 .2018 \\
\text { Accepted } 10.12 .2018 \\
\end{array}$ & $\begin{array}{l}\text { to the separation or structuring of the collagen structure (of } \\
\text { the dermis). The most effective separation of protein struc- } \\
\text { ture undergoes an ash process under the influence of alka- } \\
\text { line materials. } \\
\text { The article is devoted to studying changes of properties }\end{array}$ \\
\hline $\begin{array}{l}\text { Corresponding author: } \\
\text { O. Okhmat } \\
\text { E-mail: } \\
\text { npnuht@ukr.net }\end{array}$ & $\begin{array}{l}\text { of collagen in liming processes under the influence of } \\
\text { hydroxyl and carboxyl-containing products. The authors stu- } \\
\text { died changes in the protein structure in order to influence the } \\
\text { cockle of the hides of cattle. Studies are carried out for systems } \\
\text { of fermented protein. } \\
\text { To investigate the transformation of collagen a surface } \\
\text { tension has been determined, turbidimetric titration has been } \\
\text { performed on the level of the number of molecules. It is } \\
\text { shown that the largest protein transformation is observed } \\
\text { with the stepwise introduction of hydroxyl- and carboxyl- } \\
\text { containing products. The combination of the proposed mate- } \\
\text { rials allows to directly influence the skin folds. Structural } \\
\text { integrity of the dermis is not violated. }\end{array}$ \\
\hline
\end{tabular}

DOI: $10.24263 / 2225-2924-2018-24-6-9$

\section{БІЛКОВІ ТРАНСФОРМАЦІЇ У БІОПОЛІМЕРАХ ТВАРИННОГО ПОХОДЖЕННЯ}

\author{
О.А. Охмат, О.Р. Мокроусова, Л.А. Майстренко \\ Київський наиіональний університет технологій та дизайну
}

Шкіряний покрив тварин є біологічним об'єктом, структура якого утворена просторовою формою колагену. В технологї виробництва шкіри колагенова структура, яка містить велику кількість активних груп різної природи, піддається хімічній, фізичній і механічній трансформачї̈. Дія хімічних реагентів на білкову складову призводить до розділення або структурування колагенової структури (дерми). Найефективнішого розділення білкова струк- 
тура зазнає при проведенні відмочувально-зольних (підготовчих) прочесів під дією лужних матеріалів.

Стаття присвячена вивченню змін властивостей колагену дерми у відмочувально-зольних прочесах під впливом гідроксил- $i$ карбоксилвмісних продуктів. Авторами вивчаються зміни білкової структури з метою впливу на такий дефект шкур великої рогатої худоби, як борушистість (складки вороткової частини). Дослідження проводять для систем виплавленого білка.

Для вивчення трансформачї колагену проведено ряд реологічних досліджень, визначено поверхневий натяг, рівень формолового числа, виконано турбидиметричне титрування. Доведено, що найбільша трансформачія білка спостерігається при стадійному введенні гідроксил- та карбоксилвмісних продуктів. Комбінація запропонованих матеріалів дає змогу вплинути безпосередньо на складки шкури, не порушуючи при цььому структурну иілісність дерми.

Ключові слова: структура колагену, підготовчі процеси виробництва шкіри, гідроксил- и карбоксилвмісні продукти, трансформація білка.

Постановка проблеми. Шкіряний покрив тварин - біологічнй об’єкт, утворенй просторовою формою основного білка (колагену). Колаген $\epsilon$ амфотерним електролітом 3 властивостями гідрофільного матеріалу з обмеженим ступенем набухання. За рівня $\mathrm{pH}$, близького до ізоелектричної точки, $\mathrm{i}$ за відсутності інших електролітів колаген набуває властивостей біполярного іону і стає електронейтральним. У лужному середовищі колаген набуває від'ємного заряду, в кислому - позитивного.

Колаген характеризується структурною упорядкованістю, в якій розрізняють декілька послідовних рівнів [1]: первинний (послідовність розташування амінокислотних залишків у поліпептидних ланцюгах), вторинний (просторова конформація цих поліпептидних ланцюгів), третинний (розташування поліпептидних ланцюгів у структурі тропоколагенової частинки) і четвертинний (утворення фібрил з тропоколагенових частинок).

Розрізняють також мікро- і макрогістоструктуру колагену. Мікроструктура характеризує просторове розташування фібрил всередині колагенових волокон і їх пучків; макроструктура - просторове сплетення колагенових пучків між собою. Елементи структури колагену зв'язані між собою ковалентними і водневими зв'язками, а також зв'язками, утвореними іонною та гідрофобною взаємодією [2].

У технології виробництва шкіри колагенова структура, яка містить велику кількість активних груп різної природи, піддається хімічній, фізичній і механічній трансформації. В основі процесів виробництва натуральної шкіри лежить дія різноманітних хімічних реагентів на білкову складову, яка призводить до розділення або структурування колагенової структури (дерми).

Найефективнішого розділення білкова структура зазнає під час проведення підготовчих процесів (відмочувально-зольних). Під дією лужних матеріалів, таких як гідроксид кальцію, сульфід і гідросульфід натрію, відбувається переважно поздовжнє розщеплення білкової структури з розривом 
різних видів міжмолекулярних зв'язків. У результаті обробки сировина (шкура) перетворюється в голину. Лужні реагенти впливають одночасно на всі протеїни дерми: фібрилярні (колаген, кератин, еластин, ретикулін); глобулярні (альбуміни, глобуліни); протеїди; глікопротеїди або мукоїди, фосфопротеїди, ліпопротеїди, хромопротеїди [1]. Відбувається очищення колагенової волокнистої структури й практично повне видалення епідермальних $\mathrm{i}$ кератинових протеїнів. При цьому такі складові шкури як ліпіди, еластин i ретикулін більше видозмінюються, ніж видаляються зі шкури [3; 4].

Після проведення підготовчих процесів колагенова структура стає більш доступною для різних хімічних матеріалів. Але при переробці сировини великої рогатої худоби з'являються труднощі, пов'язані з наявністю у воротковій частині шкури молодих і дорослих биків складок різної глибини. Причому 3 віком тварини ці складки стають грубішими. Наявність складок на шкурах великої рогатої худоби характеризує дефект борушистість (воротистість), який на сьогодні $€$ невиправним. $€$ теорія [2; 4], що причина появи борушистості - «дозрівання» колагену. Ефект проявляється в утворенні додаткових міцних поперечних зв'язків і мембран, що ізолюють один від одного структурні елементи колагенової структури. Диспергування колагену при цьому зменшується, а певна кількість амінокислотних залишків у поліпептидних ланцюгах видозмінюється. Для сировини великої рогатої худоби описаний ефект спостерігається у переході дефекту «молочних смуг» на шкурах телят у грубі складки на шкурах дорослих некастрованих биків. Вважають [5], що такі складки утворені глікопротеїном - мікрофібрилярним білком, який містить багато вуглеводів. Видалення глікопротеїнів відбувається у підготовчих процесах з руйнуванням хімічних і фізичних зв'язків у структурі білка. Процес зоління проводять за таких умов, щоб досягти необхідного ступеня розволокнення структури колагену дерми без розриву зв'язків у головних поліпептидних ланцюгах протеїну. Під час проведення підготовчих процесів протеїни дерми зазнають суттєвого впливу лужних реагентів, змінюючи свої властивості.

Різка зміна рівня $\mathrm{pH}$ в бік його підвищення спричинює дисоціацію карбоксильних і основних груп амінокислотних залишків, відщеплення аміаку від амідів аспарагінової та глутамінової кислот, розрив електровалентних і водневих зв'язків, руйнування поперечних міжмолекулярних і внутрішньомолекулярних зв'язків, розрив зв'язків у головних ланцюгах з утворенням вільних аміно- та карбоксильних груп, посилене набухання колагену (структура переходить у стан бубняви), ослаблення міжмолекулярних зв'язків у головних ланцюгах, відщеплення гуанідінової групи аргініну [1;6]. Однак застосування наявних технологій не дає змоги розволокнити структуру дерми до стадії зникнення борушистості з поверхні шкур. Окрім того, виникають ускладнення при видаленні сполук кальцію, застосованого для зоління, зі структури дерми. Саме тому доцільно розробити таку технологію відмочувально-зольних процесів, яка б забезпечила, з одного боку, максимальне збереження властивостей структури дерми, а 3 іншого - зменшення прояву борушистості. Для реалізації такої мети необхідно звернути увагу на особливості проведення відмочувально-зольних процесів 3 урахуванням сучасних 
уявлень про будову колагену дерми. Найперспективнішим на сьогодні $\epsilon$ застосування у зольних процесах виробництва шкіри окислювальних систем.

Метою статті $є$ дослідження можливості трансформації колагену дерми шкур тварин гідроксил- та карбоксилвмісними сполуками.

Матеріали і методи дослідження. Аналітичні дослідження проводили на зразках напівфабрикату голини, отриманого з сировини бичини масою 35 кг. Для отримання зразків голини у відмочувально-зольних процесах використали комплекс хімічних матеріалів, що включає триетаноламін (ТЕА-ТУ У 600205601.068-2000), суміш дикарбонових кислот (СДК-ТУ У 24.1-05607824045:2007) - мурашиної, щавлевої, винної та пероксид водню (ГОСТ 177-88). Для оцінки ефективності трансформації біополімеру гідроксил- та карбоксилвмісними продуктами використали виплавлені системи цього біополімеру. Поверхневий натяг систем визначили сталагмометричним методом шляхом підрахунку крапель [6]. Молекулярно-масовий розподіл у системах виплавленого білка визначили турбидиметричним титруванням розчину осаджувачем (етиловим спиртом) з реєстрацією помутніння, яке фіксував фотоколориметр-нефелометр [7]. Визначення формолового числа за методом Серенсена [8] дало змого обрахувати кількість аміногруп, що утворились під час гідролізу білків у дослідженні. Заряд (дзета-потенціал) зразків голини визначено індикаторним методом [2].

Викладення основних результатів дослідження. Підготовчі процеси для зразків проведено за температури $26^{\circ} \mathrm{C}$ в дві стадії (табл. 1) з використанням комплексу хімічних матеріалів. ТЕА і СДК взяті для дослідження в співвідношеннях 1:1, 1:2, 1:3 або 2:1, 3:1 відповідно. Для дослідних варіантів також варіювалась витрата комплексу хімічних матеріалів на окремих стадіях проведення процесів: максимальна витрата на першій стадії; максимальна витрата на другій стадії; рівні витрати на обох стадіях. Загальна тривалість процесів склала 12 годин.

Таблиця 1. Характеристика підготовчих процесів при переробці крупної сировини великої рогатої худоби

\begin{tabular}{|c|c|c|}
\hline Процес & $\begin{array}{l}\text { Витрата матеріалів, } \\
\text { \% від маси сировини }\end{array}$ & Порядок виконання \\
\hline Відмочування & $\begin{array}{c}\text { Поверхнево-активна } \\
\text { речовина - } 0,2 \\
\text { Гідроксид кальцію - 0,3 } \\
\text { Сульфід натрію - 0,15 }\end{array}$ & $\begin{array}{c}\text { Процес проводиться за постійного обертання. } \\
\text { Лужні реагенти вводяться у робочий розчин } \\
\text { у розчиненому вигляді }\end{array}$ \\
\hline \multirow[b]{2}{*}{ Зоління } & \begin{tabular}{|c|}
1 стадія: \\
Пероксид водню-0,1-0,4 \\
Комплекс хімічних \\
матеріалів -0,15-0,60 \\
Карбонат натрію - 1,7
\end{tabular} & $\begin{array}{c}\text { У відпрацьовану відмочувальну рідину } \\
\text { додається пероксид водню, а через } 1 \text { год } \\
\text { вводиться комплекс хімічних матеріалів і } \\
\text { розчин карбонату натрію }\end{array}$ \\
\hline & $\begin{array}{c}\text { стадія: } \\
\text { Гідроксид кальцію -2,0 } \\
\text { Сульфід натрію - 2,0 } \\
\text { Пероксид водню - 0,1-0,4 } \\
\text { Комплекс хімічних } \\
\text { матеріалів - } 0,15-0,60\end{array}$ & $\begin{array}{c}\text { Через } 5 \text { годин від початку процесу } \\
\text { перевіряється рівень рН ( 10), додається } \\
\text { суспензія гідроксиду кальцію, а через } 10 \text { хви- } \\
\text { лин - розчин сульфіду натрію, пероксид } \\
\text { водню та комплекс хімічних матеріалів. }\end{array}$ \\
\hline
\end{tabular}


Повну прозоленість отриманих зразків підтверджено визначенням характерних для голини аналітичних показників (ферментативно-термічна стійкість, температура зварювання) та проведеною органолептичною (стан бубняви) оцінкою [6].

Подальші дослідження проведені для білка, виплавленого 3 отриманих зразків. Виплавляння протягом 2 год за температури $70^{\circ} \mathrm{C}$ проведено при співвідношенні маси голини та води 1:5 відповідно.

При проведенні турбидиметричного титрування білкових систем за порогом осаджуваності визначено середньозважену молекулярну масу білка в дослідних системах. Виявлено, що із збільшенням кількості гідроксильних і карбоксильних груп, введених при обробці на першій стадії підготовчих процесів, підвищується і ступінь виплавляння білка. Найменший рівень молекулярної маси $(10,2$ г) мали білкові фракції, отримані із систем, для яких на початковій стадії виконувалась обробка максимальною кількістю реагентів. Формолове число при цьому складає 0,22 . Найбільшого рівня маси $(21,6$ г) досягнуто в зразках, для яких на стадії обробки використали максимальну кількість пероксиду водню $(0,4 \%)$, яка призвела до агломерації білка, зменшуючи таким чином його виплавляння. Формолове число при цьому складає 0,45 . Виявлено також, що із збільшенням маси білкової складової, збільшується і поверхневий натяг всієї системи.

При проведенні досліджень виявлено, що із співвідношенням триетаноламіну та суміші кислот на першій стадії $3: 1$, на другій стадії $1: 2$ відповідно, досягнуто найбільш суттєвого впливу на білок. Загальні витрати матеріалів при цьому на першій стадії складають $0,6 \%$, а на другій - $0,45 \%$ маси сировини. Триетаноламін, що несе позитивний заряд, може екранувати від'ємно заряджені групи білка (переважно карбоксильні); карбоксильні групи дикарбонових кислот, навпаки, екранують позитивно заряджені групи білка (амінота пептидні). Введення у систему високореакційної низкьомолекулярної складової пероксиду водню дало змогу не тільки екранувати від'ємно заряджені групи, але й зруйнувати частину водневих зв'язків, які утримують спіраль колагену в скрученому стані. Вочевидь частина впорядкованої зони структури колагену при дії комплексу матеріалів руйнується, рухомість системи в цілому та іiі окремих складових зросла, що і призвело до додаткового розволокнення.

Одночасне використання в підготовчих процесах виробництва шкіри триетаноламіну та дикарбонових кислот буде спричиняти утворення алкоголятів 3 лужними металами, і водночас сприятиме солеутворенню між протонованим азотом і карбоновою кислотою. При дисоціації продукти першої реакції утворюють перенасичені концентрації лужних і лужноземельних металів в одній точці. Молекули алкоголятів взаємодіятимуть лише на поверхні волокон, тобто там, де $\epsilon$ потовщені складки, які й утворюють борушистість. Структурна ж цілісність всієї дерми при цьому збережеться. Доведено [2], що основна модифікація структури колагену дерми відбувається при виконанні процесу зоління і залежить від додаткової надлишкової кількості іонів 3 від’ємним зарядом, введених у систему. Визначення [2] дзета-потенціалу, 
тобто заряду, що утворився внаслідок дисоціації рухомих низькомолекулярних іонів, підтвердило наявність від'ємного знаку заряду всіх дослідних систем. Рівень показника коливається в межах від -8 до -13 . Зрозуміло, що від'ємність заряду забезпечує введення в білкову систему великого числа карбоксильних і гідроксильних груп.

\section{Висновки}

Суттєвої трансформації білкової складової дерми можна досягти ії обробкою різними гідроксил- та карбоксилвмісними сполуками. Трансформація проявляється у збільшені рухливості білкової системи, з одночасним екрануванням позитивно і від'ємно заряджених активних груп білка дерми при проведенні процесу зоління, в руйнуванні частини водневих зв'язків структури білка, у введенні в структуру білка надлишкового від'ємного заряду. Все перелічене сприятиме додатковому розволокненню дерми в підготовчих процесах і зменшенню прояву борушистості на шкурах великої рогатої худоби.

\section{Література}

1. Андреєва О.А. Поліфункціональна природа колагену як основа одержання та застосування сполук багатоцільового призначення для обробки шкір. Вісник КНУТД. 2005. № 3(23). C. $90-97$.

2. Горбачов А.А., Кернер С.М., Андреєва О.А., Орлова О.Д. Основи створення сучасних технологій виробництва шкіри та хутра: монографія. Київ: Наукова думка, 2007. 190 с.

3. Ліщук В.І., Журавський В.А., Олійник М.М. Регулювання властивостей голини. Легка промисловість. 1989. № 4. С. 26-27.

4. Михайлов А.Н. Коллаген кожного покрова и основы его переработки. Москва: Легкая индустрия, 1971. $528 \mathrm{c}$.

5. Соколов В.Е., Петрищев Б.И. Кожный покров домашних млекопитающих (копытных). Москва: Легк. индустрия, 1997. 272 с.

6. Данилкович А.Г., Чурсин В.И. Аналитический контроль в производстве кожи и меха. Лабораторный практикум: учебное пособие. Москва: МГУДТ, 2014. 170 с.

7. Біофізична та колоїдна хімія / А.С.Мороз, Л.П. Яворська, Д.Д.Луцевич та ін. Вінниця: Нова книга, 2007. 600 с.

8. Кучеренко М.Є., Бабенюк Ю.Д., Войцицький В.М., Гавриле В.І. Біохімія: практикум Київ: Либідь, 1995. 152 с.

9. Інноваційні технології виробництва шкіряних і хутрових матеріалів та виробів: монографія / А.Г. Данилкович, І.М. Грищенко, В.І. Ліщук, В.П. Плаван, Е.С. Касьян та ін.; за ред. А.Г. Данилковича. Київ: Фенікс, 2012. 344 с. 